\title{
Clinical and epidemiological profile of leprosy patients attended at Ceará, 2007-2011*
}

\author{
Maria Iranilda Queirós ${ }^{1}$ \\ Carlos Henrique Morais Alencar ${ }^{1}$ \\ Amanda Lima Sena ${ }^{1}$
}

\author{
Alberto Novaes Ramos Júnior ${ }^{1}$ \\ Lorena Dias Monteiro ${ }^{1}$ \\ Jaqueline Caracas Barbosa ${ }^{1}$
}

DOI: http:/ /dx.doi.org/10.1590/abd1806-4841.20164102

\begin{abstract}
BACKGROUND: Leprosy is an infectious chronic condition associated with potentially serious physical, social and psychological impacts.

Oвjectives: To characterize the clinical and epidemiological profile of leprosy patients treated from 2007 to 2011 in the University Hospital of Ceará, Northeastern Brazil.

Methods: This is a retrospective and descriptive study. The study population consisted of residents in the state of Ceará treated in a dermatology clinic between 2007-2011. Clinical and epidemiological data analyzed were obtained from medical records and from the database of national Information System for Notifiable Diseases.

RESUlTS: 475 cases were analyzed, mostly women (51.8\%), aged $45-59$ years (35.0\%) - mean of 45.2 years at diagnosis - with $6.3 \%$ of children under 15 , with low education $(73.7 \%)$, white color $(68.8 \%)$, residency in the city of Fortaleza (82.3\%), and no defined work occupation (59.6\%). At diagnosis, most patients were multibacillary (MB) $(65.5 \%)$, had borderline clinical form $(48.0 \%)$, and $22.7 \%$ had physical disability $(8.0 \%$ with grade 2$)$, predominantly in MB cases ( $p$ <0.001). We observe worsening of disability in $5.1 \%$ of cases post-MDT. The proportion of cases with reactional episodes was $42.7 \%$, mainly during MDT $(51.2 \%)$.

ConClusion: This is the first study conducted in this hospital context, revealing late diagnosis, high burden of disease, hidden endemicity, and high social vulnerability in the state of Ceará. This study reinforces the need to strengthen health care network for timely diagnosis and treatment, aiming at longitudinality of assistance.

Keywords: Epidemiology; Health of people with disability; Health services; Leprosy
\end{abstract}

\section{INTRODUCTION}

Leprosy is characterized as an infectious granulomatous disease, with insidious onset, caused by Mycobacterium leprae. It affects preferably skin and peripheral nerves, constituting the main infectious condition responsible for physical disability in human population associated with different social, economic and psychological impacts. It presents high infectivity and low pathogenicity, with an incubation period ranging from seven months to ten years. ${ }^{1-4}$

Leprosy is one of the oldest diseases that affect humans and that, even after the initiation of treatment with specific multidrug therapy (MDT) in mid-1986, it remains a relevant and priority public health problem in Brazil, mainly in the states of the North, Northeast and Midwest. ${ }^{5,6}$ In fact, its neglected disease feature systematically undermines its control. ${ }^{7}$

In addition to individual factors, unfavorable social conditions, such as low educational level and extreme poverty, are associated with the onset of the disease. ${ }^{3,5}$ Susceptibility is linked to nutritional, genetic and environmental factors, vaccination with BCG (Bacillus Calmette Guerin), as well as issues related to the immune system. ${ }^{8,9}$

\footnotetext{
Received on 09.10.2014

Approved by the Advisory Board and accepted for publication on 04.09.2015

Study performed at Hospital Universitário Walter Cantídio - Universidade Federal do Ceará (HUWC-UFC) - Fortaleza (CE), Brazil. Financial Support: None.

Conflict of Interest: None.

1 Universidade Federal do Ceará (UFC) - Fortaleza (CE), Brazil.
}

(C2016 by Anais Brasileiros de Dermatologia 
In 2012, the global prevalence reached 232,857 new cases and in the first quarter of 2013 there were 189,018 cases. Brazil recorded a higher detection rate of 10 cases per 100,000 inhabitants, being the primary responsible for the disease in the American continent, with $92 \%$ of the 36,178 new cases detected in the Americas. ${ }^{6}$ The state of Ceará ranks 14th in the country and the 4 th in the Northeast region in the number of new cases of the disease..$^{10}$ In the 2001-2012 period, there was a reduction in the detection rate; still, this indicator reached 24 cases per 100,000 inhabitants in 2012, considered "very high", according to Ministry of Health parameters. The city of Fortaleza is considered a priority in the national plan of strategic actions to control leprosy. ${ }^{10}$

The inherent challenges to control leprosy bring the need for structuring a resolutive and integrated network of health attention, with defined territorial base, in order to create opportunities for actions to promote health and education, early diagnosis and treatment, and rehabilitation, aiming at completeness. In this network, the role of reference units must be monitored and evaluated in order to streamline this process.

In the context of a university hospital with referral service for treatment of leprosy, this study aims at characterizing the clinical and epidemiological profile of leprosy in patients treated from 2007 to 2011 in Fortaleza.

This is the first comprehensive study of characterization of demand for this service, with the proposal to support and enhance comprehensive care for patients affected by leprosy and assist in the planning of control actions.

\section{METHODS}

This is a descriptive study of retrospective nature, based on analysis of leprosy cases treated at the University Hospital Walter Cantídio, from 2007 to 2011.

The outpatient care for leprosy in the hospital comprises the diagnosis and treatment of disease, monitoring and treatment of leprosy reaction episodes (LRE) or other complications of the disease and of multidrug therapy (MDT). Moreover, hospitalizations resulting from these complications are also comprised.

Data in this study population were obtained through a systematic review of the medical records, with complementation from the Notifiable Diseases Information System (SINAN-leprosy) database. ${ }^{11}$ In the collection of data, sociodemographic, clinical and epidemiological variables were included, such as place of residence, place of birth, occupation according to the Brazilian Classification of Occupations (BCO), age, gender, skin color, educational level, number of skin lesions and affected nerve trunks, histopathology and occurrence/ type of reaction episodes. For the variables "operational rating", "clinical form", "bacilloscopy" and "simplified standardized neurological assessment parameters", the moments before and after MDT were taken as reference. The degree of disability evolution for cases with identified evaluation was assessed. ${ }^{11}$

For the consolidation of the data, we used the statistical program Epi-info (version 3.5.2, Centers for Disease Control and Prevention, Atlanta, USA). In addition to the descriptive analysis for the calculation of potential statistical differences regarding the relative frequencies, we used the Pearson chi-square, considering significance with $p$ value less than 0.05 . The prevalence ratios and their 95\% confidence intervals (CI) were also calculated. The McNemar test was used to compare the degree of disability of individuals at diagnosis and at patient discharge. All data analysis was performed using Stata 11 (Stata Corporation, College Station, USA).

The study was approved by the Ethics Committee of the Universidade Federal do Ceará (protocol number 008.02.12).

\section{RESULTS}

In the period from 2007 to 2011, 480 cases of leprosy were treated, ranging from 75 cases in 2011 to 119 cases in 2007 . We excluded $4(0.8 \%)$ cases due to change in diagnosis and $1(0.2 \%)$ due to residing in other state than Ceará. At the end, the study population consisted of 475 patients, with epidemiological and clinical data presented in tables 1 and 2, respectively.

Mean age was 45.2 years, ranging from 4 to 89 years, standard deviation (SD) of 17.8 years and median of 47 years. The most affected age group was 4559 years, with $166(35.0 \%)$ cases. Most patients were female $(246 ; 51.8 \%)$ and white $(327 ; 68.8 \%)$. Most also had low educational level (351; 73.7\%), considering all categories until incomplete elementary education. Furthermore, the majority of patients were born in the city of Fortaleza $(239 ; 50.3 \%)$ and resided therein (391, $82.3 \%$ ) (Table 1 )

In clinical terms, $225(47.4 \%)$ patients had more than 5 skin lesions. Dimorphic clinical form was the most frequent, both at diagnosis $(228 ; 48.0 \%)$ and at discharge $(233 ; 49.0 \%)$. There were more cases with multibacillary (MB) operational classification: 311 $(65.5 \%)$ and $314(66.1 \%)$, respectively, at diagnosis and at discharge (Table 2).

Prior to the treatment, $465(97.8 \%)$ patient performed bacilloscopic exam from intradermal shaving (bacilloscopy). Of those who performed bacilloscopy at diagnosis, $136(28.7 \%)$ were positive. The mean bacilloscopic index at diagnosis was 1.6, with a standard deviation of 0.6 . When analyzed by histopathol- 
ogy, $130(27.3 \%)$ cases did not perform this exam at diagnosis, and in $83(17.4 \%)$ cases this exam was inconclusive (Table 2).

At diagnosis, 297 patients presented affected nerve trunks. The higher frequency of nerve involvement at diagnosis and at discharge was the ulnar nerve, with $154(32.4 \%)$ and 57 (12.4\%) cases, respectively. The evaluation of the degree of disability in the three segments (eyes, hands and feet) at diagnosis was observed in $458(96.4 \%)$ cases. Feet were the most affected, with $136(29.6 \%)$ cases showing some degree of physical disability, followed by hands, with 84 (18.3\%) cases, and eyes, with 24 (5.2\%) cases.

TABLE 1: Sociodemographic characterization of people attended at Hospital Universitário Walter Cantídio, Fortaleza - CE, 2007-2011

\begin{tabular}{|c|c|c|}
\hline Variable & Number & Percentual \\
\hline \multicolumn{3}{|l|}{ Age (years) } \\
\hline$<15$ & 30 & 6.3 \\
\hline $15-29$ & 62 & 13.0 \\
\hline $30-44$ & 117 & 24.7 \\
\hline $45-59$ & 166 & 35.0 \\
\hline$\geq 60$ & 100 & 21.0 \\
\hline \multicolumn{3}{|l|}{ Gender } \\
\hline Female & 246 & 51.8 \\
\hline Male & 229 & 48.2 \\
\hline \multicolumn{3}{|l|}{ Education } \\
\hline None & 18 & 3.8 \\
\hline $\begin{array}{l}\text { 1st to } 4 \text { th grade incomplete - } \\
\text { elementary school }\end{array}$ & 77 & 16.2 \\
\hline 4th grade complete - elementary school & 162 & 34.1 \\
\hline $\begin{array}{l}\text { 5th to } 8 \text { th grade incomplete - } \\
\text { elementary school }\end{array}$ & 94 & 19.8 \\
\hline Completed elementary school & 28 & 5.9 \\
\hline Incomplete high school & 22 & 4.6 \\
\hline Complete high school & 30 & 6.3 \\
\hline Incomplete higher education & 6 & 1.3 \\
\hline Complete higher education & 4 & 0.8 \\
\hline \multicolumn{3}{|l|}{ Skin color } \\
\hline White & 327 & 68.9 \\
\hline Black & 21 & 4.4 \\
\hline Yellow & 40 & 8.4 \\
\hline Brown & 79 & 16.6 \\
\hline Indian & 1 & 0.2 \\
\hline \multicolumn{3}{|l|}{ Place of birth } \\
\hline Ceará. city of Fortaleza & 239 & 50.3 \\
\hline Ceará. other cities & 103 & 21.7 \\
\hline Other States & 3 & 0.6 \\
\hline \multicolumn{3}{|l|}{ Place of residence } \\
\hline Fortaleza & 391 & 82.3 \\
\hline Ceará (other cities) & 83 & 17.5 \\
\hline Unknown & 1 & 0.2 \\
\hline
\end{tabular}

TABLE 2: Clinical and epidemiological characterization of people attended at Hospital Universitário Walter Cantídio, Fortaleza - CE, 2007-2011.

\begin{tabular}{|c|c|c|c|c|}
\hline \multirow[t]{2}{*}{ VARIABLE } & \multicolumn{2}{|c|}{ DIAGNOSIS } & \multicolumn{2}{|c|}{ DISCHARGE } \\
\hline & Number & $\%$ & Number & $\%$ \\
\hline \multicolumn{5}{|l|}{ Number of lesions } \\
\hline$>5$ & 225 & 47.4 & - & - \\
\hline$\leq 5$ & 250 & 52.6 & - & - \\
\hline \multicolumn{5}{|l|}{ Clinical form } \\
\hline Indeterminate & 18 & 3.9 & 19 & 4.0 \\
\hline Tuberculoid & 149 & 31.4 & 145 & 30.5 \\
\hline Dimorphic & 228 & 48.0 & 233 & 49.0 \\
\hline Virchowian & 73 & 15.3 & 70 & 14.7 \\
\hline Neural & 7 & 1.4 & 8 & 1.7 \\
\hline \multicolumn{5}{|c|}{ Operacional classification } \\
\hline Paucibacillary & 164 & 34.6 & 161 & 34.0 \\
\hline Multibacillary & 311 & 65.4 & 314 & 66.0 \\
\hline \multicolumn{5}{|l|}{ Bacilloscopy } \\
\hline Not performed & 8 & 1.7 & 331 & 69.8 \\
\hline Positive & 136 & 28.7 & 67 & 14.0 \\
\hline Negative & 329 & 69.2 & 58 & 12.2 \\
\hline \multicolumn{5}{|l|}{ Histopathology } \\
\hline Not performed & 130 & 27.4 & - & - \\
\hline Inderterminate & 13 & 2.8 & - & - \\
\hline Tuberculoid & 130 & 27.4 & - & - \\
\hline Dimorphic & 35 & 7.3 & - & - \\
\hline Virchowian & 78 & 16.4 & - & - \\
\hline Neural & 1 & 0.2 & - & - \\
\hline Unconclusive & 83 & 17.5 & - & - \\
\hline
\end{tabular}

At diagnosis, of the 458 (96.4\%) cases with evaluation performed, $94(20.5 \%)$ presented some degree of physical disability, $54(57.4 \%)$ had grade 1 and 33 $(42.6 \%)$ had grade 2 . At discharge, of the $388(81.7 \%)$ cases evaluated, $108(27.8 \%)$ had some degree of physical disability, $70(64.8 \%)$ had grade 1 and 38 (35.2\%) had grade 2. It is noteworthy that $21(5.4 \%)$ cases presented progression of the degree of disability, 355 $(91.5 \%)$, maintenance, and $7(1.8 \%)$ cases presented regression of disability (Table 3). Seventeen cases (3.5\%) were not evaluated at diagnosis and $87(18.3 \%)$ cases were not evaluated at discharge.

We observed a high proportion of maintenance in the degree of disability between diagnosis and post-discharge evaluation (93.5\%). Also, there was an improvement of $4.7 \%$ and worsening of $1.8 \%$ of the 383 cases evaluated in both stages. However, when comparing individuals diagnosed without physical disabilities to those with some degree of disability at discharge, there was a statistically significant difference by the McNemar test $(p=0.028)$ between the two periods of evaluation.

Physical disabilities at diagnosis were more frequent in men, with $39(17.0 \%)$ presenting grade 1 
and $24(10.4 \%)$ grade $2(p=0.009)$. Although not significant from a statistical point of view, men had a 1.30 higher chance, in relation to women, to have grade 2 disability (95\% CI: 0.97 to $1.75 ; \mathrm{p}=0.09$ ). At discharge, there were no statistical difference in cases with grade 2 disability between genders ( $\mathrm{PR}=1.30 ; 95 \% \mathrm{CI}: 0.97$ to $1.75 ; \mathrm{p}=0.08$ ).

Among the cases with grade 1 disability at diagnosis, $47(13.6 \%)$ were between $15-59$ years and 22 $(22.0 \%)$ were 60 years or older. For grade $2,25(7.2 \%)$ cases were $15-59$ years and $8(8.0 \%)$ cases, 60 years or older. At discharge, 50 (14.5\%) patients, aged between

TABLE 3: Evolution of the degree of disability at diagnosis and MDT discharge in patients assisted at Hospital Universitário Walter Cantídio, Fortaleza CE, 2007-2011

\begin{tabular}{|c|c|c|c|c|c|c|c|c|}
\hline \multicolumn{9}{|c|}{ DEGREE OF DISABILITY } \\
\hline \multirow[t]{3}{*}{ Diagnosis } & \multicolumn{8}{|c|}{ Discharge } \\
\hline & \multicolumn{2}{|l|}{0} & \multicolumn{2}{|l|}{1} & \multicolumn{2}{|l|}{2} & \multicolumn{2}{|c|}{ NA } \\
\hline & $\mathrm{N}$ & $\%$ & $\mathrm{~N}$ & $\%$ & $\mathrm{~N}$ & $\%$ & $\mathrm{~N}$ & $\%$ \\
\hline 0 & 271 & 76.3 & 16 & 4.5 & 2 & 0.6 & 66 & 18.6 \\
\hline 1 & 7 & 10 & 51 & 72.9 & 3 & 4.2 & 9 & 12.9 \\
\hline 2 & 0 & 0.0 & 0 & 0.0 & 33 & 100.0 & 0 & 0.0 \\
\hline NA & 2 & 11.8 & 3 & 17.6 & 0 & 0.0 & 12 & 70.6 \\
\hline
\end{tabular}

*NA- Degree of disability not assessed; N- Number
15 and 59 years, and $20(20.0 \%)$ patients aged 60 years or older, had grade 1 disability. For grade 2 at the time of diagnosis, $26(7.5 \%)$ cases were aged between 15-59 years and $12(12.0 \%)$ were 60 years or more.

At diagnosis, physical disabilities predominated in MB cases, $66(21.2 \%)$ cases with grade 1 and 31 $(9.9 \%)$ with grade $2(\mathrm{p}<0.001)$. In paucibacillary $(\mathrm{PB})$ cases, $4(2.4 \%)$ patients had grade 1 and $2(1.2 \%)$ had grade $2(\mathrm{p}<0.001)$.

Among patients examined at diagnosis, there was a greater chance of physical disability in dimorphic clinical form, both for grade $1(42,60.0 \%)$ and for grade $2(17,51.5 \%$; $<$ 0.001) (Figure 1). At discharge, grade 2 disabilities were also more frequent in dimorphic clinical form, with 22 (57.8\%) cases (Figure 1).

Two hundred and three $(42.7 \%)$ participants developed some leprosy reaction episode (LRE) at different times of outpatient follow-up. Sixty-seven (33.0\%) cases presented LRE before MDT, 104 (51.2\%) during MDT and 32 (15.7\%) during and after MDT. Twenty-nine patients showed both types of leprosy reactions at different times.

Type 1 reaction episodes were more common in men, with 36 cases $(57.1 \%)$, in a rate 1.14 time higher in relation to women, but not significant (95\% CI: 0.41 to $3.11 ; p=0.77$ ). Type 2 reaction episodes were similar in both sexes: two cases in each group. Type 1 reaction episodes were more frequent in the dimorphic form, with $49(77.7 \%)$ and $47(74.6 \%)$ cases before and after treatment $(p<0.002)$, respectively.

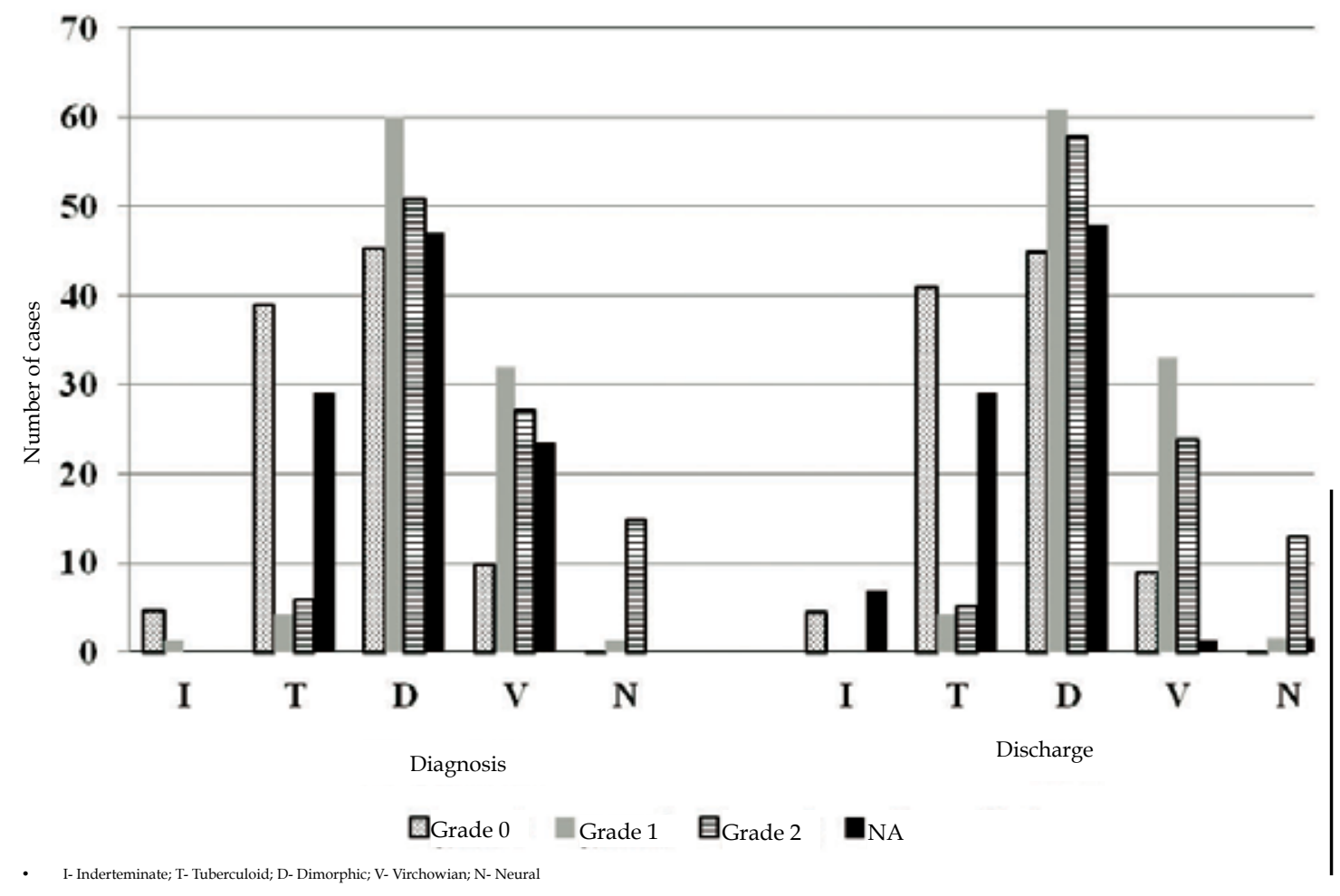

Figure 1: Degree of disability at diagnosis and discharge, according to clinical form, in patients assisted at Hospital Universitário Walter Cantídio, Fortaleza - CE, 2007-2011 


\section{DISCUSSION}

This is a pioneering study in this university hospital complex, which strengthens the neglected character of leprosy due to its large proportion, with signs of late diagnosis and associated high burden of morbidity. It reflects the clinical and epidemiological scenario of Ceará, in an area of high endemicity in Brazil, revealing the relative concentration of leprosy cases in the referral outpatient clinic whose actions should typically be the responsibility of the primary care network.

The study population included large number of working-age patients, a fact also demonstrated in other studies, with potential socio-economic consequences on families and communities. ${ }^{12,13,14}$ The neglected character of leprosy is reinforced as a poverty generating and perpetuating condition. Issues such as leprosy reaction episodes and physical disabilities extend temporary or permanent situations, such as removal of productive activities. ${ }^{15}$

Approximately one third of participants performed some paid work, according to $\mathrm{CBO}$. Of this percentage, the majority were workers in services and sellers in shops and markets, befitting the level of education. The same was demonstrated in another study. ${ }^{12}$ Such inclusion proved to be consistent with the low level of education observed in most of surveyed subjects. Moreover, most patients had no defined occupation, and many had already an established retirement.

Women showed a slight predominance, but not significant, as observed in other scenarios. ${ }^{7,16,17,18} \mathrm{Al}-$ though different from other findings in the literature, this prevalence among women may be due to factors such as specific programs focused on women's health, greater self-care, family responsibility and greater concern of women with aesthetics. ${ }^{12,19}$ The main factor for this higher occurrence among women is the increasingly integration in the job market and approximation with settings of exposure to the bacillus verified for men. On the other hand, men have lower adherence to long-term treatment due to changes in lifestyle for treatment. ${ }^{20,21}$ In this study, the impact of leprosy in the male population is relevant, even without reaching statistical significance in different analyzes. With the creation of the National Comprehensive Care Policy to Men s Health, it is expected to expand the reach of actions for this population, which may cause changes to this framework over the years. ${ }^{22}$

Despite the improvement in general education standards in the country, most of the population of this study presented uncomplete elementary school, as found by other authors, reinforced in the historical series of SINAN-leprosy database nationally. ${ }^{23}$ This finding reinforces the dimensions of social vulnerability linked to leprosy. Low education influences the level of knowledge, the access to health services, and the understanding of the disease guidelines, making the challenge to its control even more complex. ${ }^{15}$

The white color was more frequently identified in the records, disagreeing with other studies in which there was a predominance of brown color. ${ }^{24}$ Self-reference regarding color may have influenced this result in Ceará context, where most of the population in vulnerability context is concentrated between browns and whites. On the other hand, a study conducted in São Paulo showed that $54.6 \%$ of the 282 participants were white. ${ }^{14}$

There was an emphasis on the people from the city of Fortaleza. A large percentage of the study group was residing in urban areas. The large concentration of people in urban areas favors the dynamics of disease transmission in low social conditions. The inequality scenario expressed in Fortaleza reinforces its role as one of the most important cities epidemiologically in the state for leprosy. A research conducted in referral unit of the state of Ceará, with 600 users, found this same scenario. ${ }^{25}$

From a clinical point of view, the analysis of the number of lesions and the operational classification showed mild disagreement, according to the parameters of the Ministry of Health $(\mathrm{MOH})$, but it was justified when observing the number of affected nerve trunks in these patients. Although $\mathrm{MOH}$ classifies leprosy according to the number of lesions, in the practice of outpatient clinic of this study, cases are classified according to the number of lesions and the number of affected nerve trunks. The variables that refer to the number of cases with "more than five lesions" and operational classification "multibacillary", when combined, show greater possibility of sequelae and may prove difficult access to timely diagnosis. ${ }^{15}$

At diagnosis and discharge, MB operational classification predominated, especially dimorphic clinical form, with positive bacilloscopy in one third of the performed tests before treatment with MDT. These observed patterns match those of other researches, ${ }^{24,26,27}$ also revealing late diagnosis of cases. Seven cases were diagnosed as having a pure neural form, five of those performed electromyography and one performed sural nerve biopsy associated with this examination. In a study conducted in Minas Gerais, from the analysis of 19,283 new cases, four patients were found in this clinical classification. ${ }^{28}$

Reaction episodes were observed in almost $45 \%$ of the cases studied, indicating the high burden associated with these events in Ceará context, but it can also demonstrate a selection bias due to the service profile of this referral hospital. The most common reaction episode in this study was the type 1 in the dimorphic clinical form. Type 2 reaction was more frequent in cases with Virchowian clinical form, similar to other findings in the literature. ${ }^{13,28}$ Discordant data, howev- 
er, were found in a survey conducted in health centers in the city of Rio de Janeiro. Of the patients who presented reactional episode, around two thirds were classified in Virchowian clinical form. ${ }^{29}$ In this study, we found that approximately one third of the patients was referred to the clinic with reaction episodes before diagnosis. In a survey, half of the patients had type 1 reaction during treatment, requiring medical leave. ${ }^{30}$

Patients who have developed reactional episodes before MDT were sent to HUWC/UFC by professionals from other health facilities (especially primary care) for diagnostic confirmation and outpatient follow-up. We emphasized that the monitoring of leprosy reactions can be performed in primary healthcare units by skilled professionals, but in more complex cases, they should be referred to the referral units. ${ }^{11}$ This reference/ counterreference benchmark is not clearly established in Ceará, which undermines the development of a resolutive health care network that has as a reference the comprehensiveness of care.

In cases of persistent pain and normal sensory and motor setting, or without worsening, tricyclic antidepressants (amitriptyline, nortriptyline) or anticonvulsants (carbamazepine) were prescribed, as recommended by $\mathrm{MOH} .{ }^{31,32}$ Prednisone is the most prescribed drug for type 1 reaction and thalidomide for type 2 reaction. In a small percentage of patients, the combination of these two drugs was prescribed, due to the recognition of specific patterns of reactions. When necessary, there was an indication of association of other immunosuppressants, at discretion of referral services. ${ }^{32,33}$

In this study, the most affected nerve trunks at the time of diagnosis, in order of frequency, were: ulnar nerve, posterior tibial, common peroneal, and finally, median nerve. At discharge from MDT, the following order of frequency was recorded: posterior tibial, ulnar, common peroneal and median nerve. A similar result was found in the study at a leprosy referral unit in the Amazon region. ${ }^{34}$ The results of disabilities monitoring showed greater proportion at the time of diagnosis and discharge, of men, multibacillary clinical forms, age 15-59 years, with no statistically significant differences, and the feet were the segments most affected by the disease, consistent with other samples, ${ }^{13,23,27}$ confirming late diagnosis, potential hidden prevalence and unfavorable socioeconomic factors. It is noteworthy that a considerable part of the cases progressed their degree of disability.

We identified that a percentage of patients was not evaluated regarding the degree of disability at diagnosis and MDT discharge. Due to the sociocultural factor, it seems to be given greater importance to drug treatment when compared with the prevention of disabilities. Research conducted in Minas Gerais pointed out that of the 71 patients evaluated, $14 \%$ had no evaluation sequence after MDT discharge. ${ }^{15}$ In fact, this lack of longitudinality in the care undermines the planning of actions aiming at preventing disabilities.

The study presents limitations associated mainly with the secondary source of data used, the medical records. In order to qualify this basis, we used other sources, such as SINAN, complemented by simplified neurological assessment sheets. Despite this limitation, the fact of having a teaching dermatology clinic with defined protocols, stable teams for decades and engagement with research, makes this factor less relevant. Given its role in the state of Ceará health care network, this study is of significant relevance to the search for an integrated health care and assistance network for individuals affected by leprosy, not only during MDT, but also after discharge.

This aspect is central in view of the integrative role of this reference to the primary health care network, requiring innovative and qualified matricial actions, such as, for example, from second opinion, telehealth and telemedicine initiatives, and permanent distance education, aiming at enhancing the primary care network in the state.

\section{CONCLUSION}

This pioneering study of demand description in this referral service in Ceará, area of high endemicity, showed concentration of leprosy cases to build actions that would be mainly developed in primary care network. It refers to the need for potentiating the leprosy care networks with qualified reference and counterreference, including the review of actions, routines and strategies developed in this specialized clinic so far.

The reported sociodemographic profile reinforces the affected population's vulnerability context, largely in urban scenarios, demanding integrated actions of rehabilitation beyond the physical aspect, aiming at human and social development of these people.

The burden of the disease is still present in our midst, demonstrated by clinical and epidemiological profile of this study, reinforcing issues such as late diagnosis, hidden endemicity, relevance of reaction episodes and burden of physical disabilities. These evidences point to the need for integration of leprosy as a chronic condition in the health care network, with longitudinal and comprehensive care for those affected and their families. For the university hospital, it reflects the need to review its role, strengthening its actions as an educational institution. It is stressed therefore the need to integrate control actions in the health care network of Ceará.

Additional studies are needed to increase the understanding of the true epidemiological and operational scenario of leprosy in Ceará at other points in the health care network.] 


\section{REFERENCES}

1. Brasil. Ministério da Saúde. Secretaria de Vigilância em Saúde. Guia de Vigilância em Saúde. Brasília: Ministério da Saúde; 2014. 812 p.

2. Lyon S, Lyon LFP. A doença hanseníase. In: Grossi MAF, Lyon S. Hanseníase. Rio de Janeiro: Medbook; 2013. p.43-48.

3. Mendonça VA, Costa RD, Melo GEBA, Antunes CM, Teixeira AL. Imunologia da hanseníase. An Bras Dermatol. 2008;83:343-50.

4. Brasil. Ministério da Saúde. Secretaria de Políticas de Saúde. Departamento de Atenção Básica. Guia para o Controle da hanseníase. Brasília: Ministério da Saúde; 2002. (Série A. Normas e Manuais Técnicos; n. 111).

5. Oliveira MLW. Infecções por micobactérias. In: Ramos e Silva M, Castro MCR. Fundamentos de dermatologia. Rio de Janeiro: Atheneu; 2010. p.907-917.

6. World Health Organization. Weekly epidemiological record Relevé épidémiologique hebdomadaire. Global leprosy: update on the 2012 situation. Wkly Epidemiol Rec. 2013;88:365-80. [cited 2014 Apr 10]. Available from: http://www.who.int/ wer/2013/wer8835.pdf

7. Campos SSL, Ramos Jr AN, Kerr-Pontes LRS, Heukelbach J. Epidemiologia da hanseníase no Município de Sobral, Estado do Ceará-Brasil, no período de 1997 a 2003. Hansen Int. 2005; 30:167-73.

8. Kerr-Pontes LR, Barreto ML, Evangelista CM, Rodrigues LC, Heukelbach J, Feldmeier H. Socioeconomic, environmental, and behavioral risk factors for leprosy in North-east Brazil: results of a case-control study. Int J Epidemiol. 2006;35:994-1000

9. Lockwood DN, Suneetha S. Leprosy: too complex a disease for a simple elimination paradigm. Bull World Health Organ. 2005;83:230-5.

10. Saude.ce.gov.br [Internet]. Governo do Estado do Ceara. Secretaria Estadual da Saúde. Informe Epidemiológico Hanseníase - agosto de 2014. [acesso 18 set 2014]. Disponivel em: file:///C:/Users/estagio.revista/Downloads/informe_epid_ leishmaniose_ago_2014.pdf

11. Brasil. Ministério da Saúde. Portaria $n^{0} 3.125$, de 7 de outubro de 2010. Aprova as diretrizes para vigilância, atenção e controle da hanseníase [acesso 22 jul 2014]. Disponível em: http://www.anvisa.gov.br/hotsite/talidomida/legis/ portaria_n_3125_hanseniase_2010.pdf

12. Barbosa JC, Ramos Jr AN, Alencar MJF, Castro GJ. Pós-alta em hanseníase no Ceará: limitação da atividade funcional, consciência de risco e participação social. Rev Bras Enferm. 2008;61:727-33.

13. Monteiro LD, Alencar CHM, Barbosa JC, Braga KP, Castro MD, Heukelbach J. Incapacidades físicas em pessoas acometidas pela hanseníase no período pósalta da poliquimioterapia em um município no Norte do Brasil. Cad Saúde Pública. 2013; 29:909-20.

14. Romão ER, Mazzoni AM. Perfil epidemiológico da hanseníase no município de Guarulhos, SP. Rev Epidemiol Control Infect. 2013; 3:22-7.

15. Ribeiro Júnior AF, Vieira MA, Caldeira AP. Perfil epidemiológico da hanseníase em uma cidade endêmica do Norte de Minas Gerais. Rev Bras Clin Med. 2012;10:272-7.

16. Fortaleza.ce.gov.br [Internet]. Secretaria Municipal de Saúde. Hanseníase. Boletim de Saúde de Fortaleza, 2011. Disponivel em: http://www.fortaleza.ce.gov.br/

17. Lana FCF, Lima RF, Araújo MG, Fonseca PTS. Situação epidemiológica da hanseníase no município de Belo Horizonte/MG- Período 92/97. Hansen Int. 2000;25:121-32.

18. Silva AR, Matos WB, Silva CCB, Gonçalves EGR. Hanseníase no município de Buriticupu, Estado do Maranhão: busca ativa de casos na população adulta. Rev Soc Bras Med Trop. 2010;43:691-4.

19. Alencar MJF, Barbosa JC, Pereira TM, Santos SO, Eggens KH, Heukelbach J. Leprosy reactions after release from multidrug therapy in an endemic cluster in Brazil: patient awareness of symptoms and self-perceived changes in life. Cad Saúde Colet. 2013;21:450-6.

20. Amaral EP, Lana FCF. Análise espacial na microrregião de Almenara, MG, Brasil. Rev Bras Enferm. 2008; 61:701-7.

21. Jorge MSB, Guimarães JMX, Vieira LB, Paiva FDS, Silva DR, Pinto AGA. Avaliação da qualidade do programa saúde da família no Ceará: a satisfação dos usuários. Rev Baiana Saúde Pública. 2007;31:258-68.

22. Saúde.gov.br [Internet]. Brasil. Ministério da Saúde. Portaria $n^{0} 1.944$, de 27 de agosto de 2009. Institui no âmbito do Sistema Único de Saúde (SUS), a Política Nacional de Atenção Integral à Saúde do Homem [acesso 22 jul 2014]. Disponível em: http://bvsms.saude.gov.br/bvs/saudelegis/gm/2009/prt1944_27_08_2009. html.
23. Raposo MT, Raposo AVC, Sanchez-González MA, Medeiros JLA, Nemes MIB Avaliação de incapacidade em pessoas vivendo com hanseníase: análise do grau de incapacidade em Campina Grande, Paraíba. Cad Saúde Coletiva. 2009;17:221-33.

24. Miranzi SSC, Pereira LHM, Nunes AA. Perfil epidemiológico da hanseníase em um município brasileiro, no período de 2000 a 2006. Rev Soc Bras Med Trop. 2010;43:62-7.

25. Ferreira MLLT, Pontes MAA, Silveira MIS, Araújo LF, Kerr, LRS. A demanda de um centro de referência nacional para hanseníase no nordeste brasileiro: porque 0 excesso de pacientes? Cad Saúde Coletiva. 2008;16:243-56.

26. Portalsaude.saude.gov.br [Internet]. Brasil. Ministério da Saúde. Secretaria de Vigilância em Saúde. Situação epidemiológica da hanseníase no Brasil - análise de indicadores selecionados na última década e desafios para eliminação. Boletim Epidemiológico. 2013;44:1-12.[acesso em 24 abr. 2014]. Disponível em: http://portalsaude.saude.gov.br/images/pdf/2014/junho/11/BE-2013-44--11---Hanseniase.pdf

27. Teixeira MAG, Silveira VM, França ER. Características epidemiológicas e clínicas das reações hansênicas em indivíduos paucibacilares e multibacilares, atendidos em dois centros de referência para hanseníase, na cidade de Recife, Estado de Pernambuco. Rev Soc Bras Med Trop. 2010;43:287- 92.

28. Moschioni C, Antunes CM, Grossi MA, Lambertucci JR. Risk factors for physica disability at diagnosis of 19.283 new cases of leprosy. Rev Soc Bras Med Trop. 2010:43:19-22.

29. Antônio JR, Soubhia RMC, Paschoal VDA, Oliveira GB, Rossi NCP, Maciel MG, et al. Avaliação epidemiológica dos episódios reacionais e incapacidade física em pacientes com hanseníase na cidade de São José do Rio Preto. Arq Ciênc Saúde. 2011:18:9-14.

30. Silva SF, Griep RH. Reação hansênica em pacientes portadores de hanseníase em centros de saúde da Área de Planejamento 3.2 do Município do Rio de Janeiro. Hansen Int. 2007;32:155-62.

31. Brasil. Ministério da Saúde. Secretaria de Vigilância em Saúde. Departamento de Vigilância Epidemiológica. Orientações para uso: corticosteroides em hanseníase. Brasília: Editora do Ministério da Saúde; 2010. 52 p. - (Série A. Normas e Manuais Técnicos).

32. International Federation of Anti-Leprosy Associations (ILEP). Como reconhecer e tratar reações hansênicas. 2. ed. Belo Horizonte: Secretaria da Saúde do Estado; 2007.

33. Grossi MAF. Episódios reacionais. In: Grossi MAF, Lyon S. Hanseníase. Rio de Janeiro: Medbook; 2013

34. Cunha MHCM, Macedo GMM, Batista KNM, Xavier MB, Sa Neto S, Nascimento FSN. Avaliação clínica-epidemiológica em pacientes multibacilares em unidade de referência de Hanseníase da Amazônia. Hansen Int. 2008;33:9-16.

How to cite this article: Queirós MI, Ramos JR AN, Alencar CHM, Monteiro LD, Sena AL, Barbosa JC. Clinical and epidemiological profile of leprosy patients attended at Ceará, 2007-2011. . An Bras Dermatol. 2016;91(3):311-7. 